\title{
THE BANKHEAD-JONES FARM TENANT ACT
}

\author{
JAMES G. MADDOX*
}

With the enactment of the Bankhead-Jones Farm Tenant Act, ${ }^{1}$ signed by President Roosevelt on July 22nd of this year, another feature was added to the new national land policy that has been slowly evolving under the New Deal. This act gives outright and specific legislative authorization for the continuance of the federal programs of rural rehabilitation loans and submarginal land purchase and development, which have heretofore been carried out under executive orders and financed by funds from appropriations for relief and work relief projects. ${ }^{2}$ It places these programs under the administration of the Secretary of Agriculture, and, at the same time, authorizes him to inaugurate a system of long-term mortgage loans to aid landless rural families in becoming farm owners. From some viewpoints the Act is more important as a declaration of policy on the part of Congress than as an instrument for immediate accomplishments. Nevertheless, it lays the first foundation stones, upon which may eventually be built a comprehensive land program.

The following discussion of the Act has three purposes: ( $\mathrm{r}$ ) to present a resume of the legislative history of the law; (2) to describe its principal provisions which directly pertain to the promotion of farm ownership; and (3) to point out some of the obvious weaknesses of those provisions, and make suggestions for their improvement. Those sections of the Act which provide for rural rehabilitation loans to distressed families and for the purchase and development of land unsuited for farming will be only briefly mentioned. They are, however, very significant parts of the law.

Within a year after the inauguration of the cotton acreage adjustment program in 1933 and other farm relief measures which obviously redounded to the benefit of landowners, rumblings began to be heard that something should be done for farm tenants. In mid-summer of 1934 , tenants and sharecroppers in north-eastern Arkansas were meeting to organize the Southern Tenant Farmers' Union, which was incorporated under the laws of Arkansas on July 26, 1934. By the fall of that year,

* B.S.A., 1927, University of Arbansas; M.S., 1930, University of Wisconsin. On leave from the United States Department of Agriculture for study of land tenure problems in England and Denmark as a Fellow of the Julius Rosenwald Fund. Previously with the Land Use Planning Section of the Resettlement Administration.

${ }^{1}$ 50 STAT. 522, 7 U. S. C. A. $\$ \$ 1000-1029$.

${ }^{2}$ For a discussion of the legal bases of the rural rehabilitation program, see Oppenheimer, The Development of the Rural Rehabilitation Loan Program, infra, p. 473. ED. 
there had developed requests and demands for action. In several areas of the country, but especially in the South, tenants were dissatisfied, were moving from farms to towns and going on relief, and were constantly complaining that they were not receiving an equitable share of the benefit payments being made by the Agricultural Adjustment Administration for reducing cotton acreage. In general, the situation was one in which the propertyless classes of the rural South were losing the security which the traditional system had afforded them. The old plantation paternalism was breaking down, and many landlords were failing to assume their customary responsibilities toward tenants. The United States Department of Agriculture was not only receiving complaints relative to effects of the acreage reduction program on the status of southern sharecroppers and tenants, but it was also receiving, from widespread sources, numerous plans for alleviating the farm tenancy situation. Many of these were, of course, either the "crack-pot" ideas of "perpetual cranks" or vague Utopian schemes for correcting all the ills of a sadly depressed agriculture. Some of them, however, contained sound and fruitful suggestions. Several persons proposed that the federal government resell the farms which had been foreclosed on by the Federal Land Banks to tenant farmers. One plan of this general nature which reached the Secretary of Agriculture about January I, I935, was suggested by Frank Tannenbaum, who was at that time a Guggenheim Fellow and was later appointed to the faculty of Columbia University. This plan evoked more than usual interest in the various divisions of the Department of Agriculture, to which it was referred for comments, criticisms, and suggestions, partly because its proponent was well known as a student of social problems, and partly because it envisaged the establishment of an agency which would not only provide tenants and laborers with credit for the purchase of farms, but would also give them guidance and supervision in conducting their farm and home management practices. It was concerned primarily with the situation in the South, but could be adapted to all sections of the country.

Before the plan suggested by Tannenbaum had been considered by all the divisions in the Department of Agriculture to which it had been referred, Senator John H. Bankhead of Alabama expressed an interest in introducing a bill in Congress aimed at aiding tenants in becoming farm owners. He asked the Department of Agriculture to suggest the provisions which should be incorporated in such a measure. After a series of conferences and discussions among economists, sociologists, lawyers, and administrative officials of the Department of Agriculture, a suggestion was made to Senator Bankhead that a bill authorizing an annual appropriation to the Department, with which to purchase farms to be resold to tenants on long-time sales contracts, would be a start towards alleviating some of the evils of our tenancy system. ${ }^{3}$

\footnotetext{
${ }^{3}$ Tannenbaum participated in most of the conferences in which the details of this plan were developed, and for several wceks thereafter spent considerable time in explaining it to public leaders. It was similar to the plan which he had suggested to Secretary Wailace.
} 
Senator Bankhead, however, rejected the idea of starting a program which was dependent upon small annual appropriations, and chose instead to introduce a bill which provided for the formation of a government corporation, similar to the Home Owners' Loan Corporation, with powers to issue government guaranteed bonds to the extent of $\$ 1,000,000,000$.' Consequently, he introduced in the Senate on February II, I935, a bill (S. I800) known as the "Farm Tenant Homes Act of I935." With the introduction of this bill, there began the formal Congressional consideration of legislation which finally culminated in the enactment of the Bankhead-Jones Farm Tenant Act in July, 1937. There were other farm tenancy bills introduced in the first session of the 74th Congress, at least two of which were at an earlier date than the one by Senator Bankhead. These measures, however, received very little consideration after their introduction.

The Bankhead Bill (S. 1800) proposed to create a Corporation within the Department of Agriculture, "which shall be an instrumentality of the United States, and shall be under the direction of the Secretary of Agriculture, ... . and operated by him under bylaws, rules, and regulations to be prescribed by him for the accomplishment of the purposes of this Act." The bill provided that the proposed Corporation should have wide powers in its program of aiding farm tenants. It could make loans to tenants with which to purchase farms, or it could buy land and "execute contracts to convey the property to the purchaser . . . upon full compliance with all the requirements of said contract." Authorization was granted for the Corporation to make a conveyance of the property prior to the time full payment had been made by the purchasing tenant, and to take an ordinary real estate mortgage or deed of trust as security. The period for repayment of the indebtedness incurred by the tenant-purchaser was to be not less than 30 nor more than 50 years, and the rate of interest was to be "as low as the Corporation can secure the money plus a reasonable charge for administration." The Corporation was also given power to make loans to"sharecroppers and tenants with which, "to buy farm homes and farm supplies and equipment, including livestock." Obviously the program proposed by the bill was both rural rehabilitation and the promotion of farm ownership.

Hearings on this bill were held by a Subcommittee of the Committee on Agriculture and Forestry in the Senate on March 5, r935. Only eight persons appeared before the Subcommittee, and all of them were in favor of the bill. They spent most of their time in picturing the seriousness of the farm tenancy problem in the United States, in praising the bill as providing a means for coping with the problem, and in explaining in a very general way how a program, of the nature proposed by the bill could be put into operation. All of the statements were of a generalized nature, and none of them were critical of the proposal. Secretary Wallace, who was the first person to appear before the Subcommittee, closed his formal statement by saying:

"I am happy to support a measure which has as its oim the creation of a substantial group of farm owners out of our present tenant class. I know of no better means of

"79 Conc. Rec. 1782 (1935). 
reconstructing our agriculture on a thoroughly sound and permanently desirable basis than to make as its foundation the family-sized, owner-operated farm. I believe that the provisions of this bill can be put into effective operation in such manner as to bring greater individual opportunity and security to thousands of tenants. At the same time they should be of substantial aid in our crop-adjusting programs and in our attempts to conserve soil fertility and prevent erosion. Moreover, these provisions will aid materially in bringing about the development of a rural civilization embodying a higher standard of living and a better developed and more stable community life than has been possible under a system characterized by land speculation, absentee landlords, and migratory tenants."

The other persons who appeared at the hearings were practically as strong in their support of the bill as the Secretary. ${ }^{\mathbf{C}}$

Several bills, aimed at promoting farm ownership among tenants, had been introduced in the House before hearings had been held in the Senate on the proposed Farm Tenant Homes Act of r935. One of these was identical with the Bankhead Bill in the Senate. Most of them had been referred to the Committee on Agriculture, but it was not until Congressman Marvin Jones of Texas, Chairman of that Committee, took an interest in farm tenancy legislation that any of these measures received noticeable consideration. By virtue of his Chairmanship of the Committee on Agriculture, Congressman Jones was the "key" to tenancy legislation in the House. On February 25, he had introduced a bill (H. R. 615I), known as the "Agricultural Bank Note Act," which provided among other things that reduced interest rates should be granted by the Federal Land Banks and the Land Bank Commissioner on loans made to small farm owners personally engaged in the operation of their farms or to persons who wanted to purchase small farms for personal operation. The interest rate on loans to such farm owners or purchasers was not to exceed $2 \%$ per annum according to the provisions of this bill, and loans of this character were not to be granted to persons on farms, the normal value of which was more than $\$ 7,000$. Two days after hearings had closed on the Bankhead Bill in the Senate and when it was obvious that farm tenancy legislation was receiving considerable public support, Congressman Jones excerpted the section from the "Agricultural Bank Note Act" which proposed to grant mortgage loans through the Farm Credit Administration to owners and purchasers of small farms at $2 \%$ interest and introduced this section as a separate bill (H.R. 6503).

Congressman Jones was obviously interested in legislation which would promote the ownership of farms among small owners. His procedure for attacking the problem, however, was through granting lower interest rates on the farm mortgage loans made by the agencies of the Farm Credit Administration to the owners of small farms who personally operated their holdings. The bill introduced by Senator

\footnotetext{
"Hearing before a Subcommittee of the Senate Committee on Agriculture and Forcstry on S. I80o, 74th Cong., Ist Sess. (I935) I3.

- The statements before the Subcommittee should not be interpreted as a reliable index of public opinion respecting the bill. The hearings were scheduled to continue for several days, but were cut short after one day because several persons who had been asked to testify were not able to appear and others who were opposed to the measure wanted to make statements before the Subcommittee.
} 
Bankhead, on the other hand, proposed to place the administration of the program under the direction of the Secretary of Agriculture. Moreover, it authorized the Secretary of Agriculture to purchase land and resell it to tenants, sharecroppers, and laborers after a trial leasing period, as well as to make loans for the direct purchase of farms. This conflict in point of view continued to be important throughout all subsequent consideration of farm tenancy legislation. Congressman Jones apparently visualized the problem of promoting farm ownership among tenants as one which could best be administered by the Farm Credit Administration, and most adequately carried out through a procedure of granting ordinary farm mortgage credit on liberal terms. Senator Bankhead visualized the program as one which should be administered by the Department of Agriculture and should embody the procedure of land purchase and resale to tenant farmers.

These two points of view were at least partly reconciled through a series of conferences in which Senator Bankhead and Congressman Jones agreed to introduce a new bill (S. 2367) known as "The Farmers' Home Act." This measure was introduced, both in the House ${ }^{7}$ and in the Senate, ${ }^{8}$ on March 26 , 1935. Immediately, it became popularly known as the Bankhead-Jones Farm Tenancy Bill. The principal manner in which this bill differed from the one which had been introduced earlier by Senator Bankhead (S. I800) was with respect to the agency which was to administer the Act. The bill proposed to create a Farmer's Home Corporation, the management of which was to be vested in a Board of Directors "of five members, consisting of the Secretary of Agriculture and the Governor of the Farm Credit Administration as members ex-officio, and three members to be appointed by the President, by and with the advice and consent of the Senate." Obviously, this bill proposed to create a new agency, responsible neither to the Department of Agriculture nor to the Farm Credit Administration, but which had on its board of directors the principal officer of each of these agencies.

The bill was taken up for consideration on the Senate floor on April 16, 1935. It was discussed and vigorously debated for six daily sessions of the Senate. ${ }^{8}$ It was obvious from the very beginning of the discussion that the bill had considerable support. The late Senator Joseph T. Robinson, the majority leader, was in favor of its passage. This gave it an aura of Administration support, and probably gathered strength for its passage from the ranks of those senators who were willing or anxious to "go along" with the party leadership. Nevertheless, on April 24, which was the sixth day of the debate, the bill was recommitted to the Committee on Agriculture and Forestry with instructions to report it back to the Senate not later than May 12. ${ }^{10}$ The Committee made a few minor changes in the bill, although most of these were simply to clarify amendments which had been passed while the bill was under consideration on the floor of the Senate. It was reported

\footnotetext{
${ }^{7}$ H. R. 7018, 79 Cong. Rec. 4490 (1935). $\quad{ }^{8} 79$ Conc. REc. 4418 (1935). (1935).

79 CoNG. Rec. $5748,5750,5923,5937,6003,6018,6109,6116,6132,6184,6195,6204,6271-6290$ ${ }^{10} \mathrm{Id}$. at 6290 .
} 
from the Committee the second time on May 9, and came up for reconsideration on the floor of the Senate on June $2 \mathrm{I}$, I935. It was passed by a vote of 45 to $3^{\mathrm{I}^{11}}$ near the end of the third day of debate, and immediately referred to the Committee on Agriculture in the House. ${ }^{12}$

The bill passed the Senate in essentially the form it was in when introduced. Although it was amended several times none of the changes altered it in principle. The proposed Corporation still had power to issue $\$ 1,000,000,000$ in government guaranteed bonds, although it was provided that: "None of said bonds shall be issued within one year after the approval of this Act," and that, "Within three years after the approval of this Act not more than $\$ 300,000,000$ of said bonds may be issued." The capital stock of the corporation was also reduced from \$ro0,000,000 to $\$ 50,000,000$. The latter amount was to be the working fund of the Corporation during its first year of existence. In the discussions of the bill on the floor of the Senate there appeared to be general agreement among Senators that great care should be exercised to prevent the beneficiaries of the program from losing the farms which they were aided in purchasing. One amendment provided that: "No land purchased from the corporation ... u up to the value of $\$ 2,500$ shall ever be encumbered with any lien or obligation, either statutory or contractual. Such land shall not be subject to any debt, or debts, or obligations of any kind of the owner, except taxes, and every conveyance, lease or contract executed by the Corporation ... . shall contain a provision that the land shall forever remain free of all liens or encumbrances of whatever kind, and such provision shall be a covenant running with the land as long as it shall be used as a farm homestead." Although the wisdom of such a provision might be questioned on several grounds, it is, nevertheless, evidence that the Senate recognized the necessity for protecting as well as promoting farm ownership. In view of our past land policies under the homestead laws and the traditional American attitudes toward land speculation this amendment was of some significance as an attempt to evolve a new national ideology toward property in land.

Although the Committee on Agriculture in the House held hearings on the bill for one day (April I6, I935) the passage of the measure in the Senate virtually ended formal Congressional consideration of farm tenancy legislation in the 74th Congress. Only four persons testified before the House Committee on Agriculture, during the one-day of hearings, and three of these had previously appeared before the Subcommittee of the Committee on Agriculture and Forestry in the Senate. All were in favor of the objectives of the bill. From comments made during the hearings, it was evident, however, that several members of the Committee were opposed to it. Of more significance was the obvious lack of conviction on the part of any ranking member of the Committee that the tenancy problem was one needing immediate attention and that this bill offered a wise method of procedure. Evident also was a

II Id. at 9960 .

${ }^{25}$ Votes were not cast, either for or against the passage of the bill, by twenty Senators. 
general waning of interest in the fate of the measure on the part of Department of Agriculture officials. Secretary Wallace closed his statement before the Committee on Agriculture in the House, during the one day of hearings, by saying:

"I would trust . . . that the bill would not pass suddenly; I would urge that there be the greatest possible discussion in order that the bill might be made as nearly perfect as can be. I cannot help expressing the most profound interest in the objectives of the bill. I think they are absolutely sound. And because I am interested in the objectives I am also anxious that the procedure be safeguarded in every possible way so that it will not be possible for some future Congress, ro or 15 years hence, to say that this law was enacted without sufficient thought as to the mechanics, for the supervision of the tenant while beginning his first agricultural practices and habits which are necessary when a man is operating his own land."

These remarks were quite different from those previously quoted with which the Secretary had closed his statement before the Subcommittee of the Senate Committee on Agriculture and Forestry. The version of the bill on which the House Committee was holding hearings did not place the proposed corporation in the Department of Agriculture. As has been explained, it provided for the creation of a new agency to administer the tenancy program. Moreover, it had been announced that the Resettlement Administration would be organized outside of the Department of Agriculture. Both factors were important in shaping the fate of the bill in the House. Instead of gaining strength, it became a measure which had few ardent and vociferous friends. After the Resettlement Administration was organized, it was the only government agency actively sponsoring the passage of the bill in the House. Brooks Hays, special Assistant to the Administrator of the Resettlement Administration, spent practically full time in developing support for the bill both among Congressmen and public leaders. On the whole, however, Congressmen were occupied with other matters. With a few exceptions they showed a lackadaisical attitude toward the tenancy bill. The rank and file were waiting for Committee action. But the bill had definitely hit a snag in the House Committee on Agriculture, and the first session of the 74th Congress adjourned without the bill having been reported. Throughout the second session of the same Congress the bill was hardly considered by the House Committee. Congressmen were more interested in the forthcoming elections than in tenancy legislation. When the second session of the 74th Congress adjourned, in the summer of 1936 , without the bill having even been considered on the floor of the House, the prospects for legislation to aid tenants in becoming owners "reached a new low." The failure of the House to pass the bill during either the first or the second session of the $74^{\text {th }}$ Congress meant that favorable action would again have to be taken by the Senate, before the measure could become a law.

The entire period from the passage of the bill by the Senate in June, 1935, until the 75th Congress convened in January, 1937, was one in which the consideration of tenancy legislation by Congress was practically at a standstill, but, at the same time, it was a period in which the public was probably more fully informed respecting 
tenancy problems and conditions than ever before. Soon after the bill was introduced, in the spring of 1935, a wave of newspaper publicity swept the country which was concerned mainly with picturing the growth and extent of tenant farming, the activities of the Southern Tenant Farmers Union, and the principal provisions of the Bankhead-Jones Tenancy Bill. This flurry of press notices subsided somewhat after the bill passed the Senate, but an increased number of magazine articles, pamphlets and short books began to appear which discussed the tenancy situation in more constructive and critical terms. The interest which was aroused is partly indicated by the fact that both major political parties incorporated pledges in their I936 platforms to sponsor legislation to alleviate the farm tenancy situation. Soon after President Roosevelt was re-elected he appointed a special Committee on Farm Tenancy to "thoroughly examine and report on the most promising ways of developing a land tenure system which will bring an increased measure of security, opportunity, and well-being to the great group of present and prospective farm tenants." This Committee immediately set to work to prepare a report for the use of the new Congress which convened January I, 1937. Public hearings were held by subcommittees of the Committee in Indianapolis, Lincoln, San Francisco, Dallas, and Montgomery. These hearings were well advertised, attended by hundreds of people, and created much public discussion of tenancy problems. At the same time, they furnished many guideposts to the subcommittee and technical personnel engaged in drafting the report. ${ }^{13}$

When the first session of the $75^{\text {th }}$ Congress convened, the stage was set for considering farm tenancy legislation. The elections were over. The Administration had been returned to power by an overwhelming vote. Campaign promises had been made, and the Congress faced the task of fulfilling them. On January 5, I937, Congressman Jones introduced a bill in the House, called "The Farmers' Home Act" (H.R. 8), ${ }^{14}$ and the next day Senator Bankhead introduced a bill by the same title (S. I06) ${ }^{15}$ in the Senate. The bills had practically identical provisions except with respect to the management of the proposed Farmers' Home Corporation, which was to administer the program. The bill introduced by Congressman Jones provided that: "The management of the Corporation shall be vested in a board of directors consisting of three officers or employees of the United States, designated by the President of the United States, one of whom shall be from the Treasury Department, one from the Department of Agriculture, and one from the Farm Credit Administration." Senator Bankhead's bill provided that: "The management of the Corporation shall be vested in a board of directors . . . of three members, consisting of the Secretary of Agriculture, the Under Secretary of Agriculture, and the Assistant Secretary of Agriculture." The bills followed the same general prin-

\footnotetext{
21 For a list of the Committee, Technical Conmittce and persons who contributed material to the report, see Farm Tenancy, Report of the President's Conmitree (Feb. 1937) 28-30. (The Report was also printed as H. R. Doc. No. I49, 75th Cong., Ist Sess. (1937).)

10 I Cong. Rec., Jan. 5, r937, at 2I.
} 
ciples that had been incorporated in the measure which had passed the Senate in June, I935. One important difference, however, was with respect to the manner in which the program was to be financed. As has been pointed out, the 1935 bill provided that the Corporation should have an original capital of $\$ 50,000,000$ and, after the first year of operation, power to issue government guaranteed bonds to a maximum amount of $\$ 1,000,000,000$. The bills introduced by Senator Bankhead and Congressman Jones in January 1937, authorized an appropriation of $\$ 50,000,000$ for the original capital stock of the Corporation, and an additional appropriation of $\$ 50,000,000$ "for each of the ten fiscal years succeeding the first. . .." The change from a program financed by special bond issues to one dependent upon annual appropriations was in line with the suggestions which had been made to Senator Bankhead two years earlier, when he had first expressed an interest in a tenancy bill. The reduction in amount of funds represented, in part, a widespread belief that the public debt was mounting too rapidly and, in part, a recognition by government officials as well as by members of Congress that a program aimed at promoting farm ownership through the purchase and resale of land would be forced by the very nature of the work to proceed slowly.

Before the President's Committee had made its report on February 16, the Committee on Agriculture in the House had already started hearings on the bill introduced by Congressman Jones. About twenty persons submitted oral or written statements during the eleven days on which hearings were held, but little tangible progress was made until after the report of the President's Committee had been released. The Committee placed the problem of farm tenancy in a much broader framework than that in which it had usually been discussed before, definitely indicating that a program which was concerned solely with the direct promotion of farm ownership was only one small part of a more general program that was needed. Greater farm security was set forth as the major objective toward which land tenure legislation should be directed. Accordingly, the establishment of a Farm Security Administration in the Department of Agriculture was suggested. Its function would be to administer, under the direction of the Secretary of Agriculture, a broad program aimed primarily at increasing the opportunity and security of the great mass of under-privileged rural people. The findings and recommendations of the Committee indicated that its deliberations had not been concerned with tenants and tenancy alone, but had encompassed the problems and needs of all rural groups below the economic level of those who could be aided by the agencies of the Farm Credit Administration and above the level of chronic indigents and permanent relief cases. The Committee declared that: "Approximately one farm family out of four occupies a position in the Nation's social and economic structure that is precarious and should not be tolerated."16 The Committee submitted "recommendations for both Federal and State action, as well as for joint action under Federal-State co-operation."17

${ }^{18}$ Farm Tenancy, Report of the President's Committee, 4.

${ }^{17} \mathrm{~A}$ complete statement of the recommendations of the Committec will be found in the Report, supra note I3. 
The principal recommendations for federal action included "measures to tacilitate farm-home ownership and to help existing owners keep their farms, measures for the rehabilitation of groups not now prepared to take over their own farms, certain suggestions for improving the condition of laborers, a program for aiding families stranded on submarginal land and taking such land out of cultivation, and proposals for the discouragement of speculation in farm lands." 18 After the recommendations of the President's Committee had been explained to the House Committee on Agriculture and contrasted with the provisions of the bill (H.R. 8), on which the Committee had been holding hearings it was evident that a new measure was required if many of the recommendations were to be put into legislation.

When the Committee on Agriculture in the House started the task of drafting a measure on which the majority could agree and which at the same time would put into law the major recommendations of the President's Committee on Tenancy, difficulties immediately arose. Executive sessions of the Committee were, of course, not open to the public, nor are records available which indicate the nature of the discussions. Nevertheless, it is fairly clear from many scattered sources of information, including conversations with Committee members, that the real difficulty facing the group was to reach an agreement on how to proceed toward promoting farm ownership among tenant farmers. There appeared to be little disagreement over the nature of legislation authorizing rural rehabilitation and submarginal land purchase programs. Moreover, there was general agreement that something should be done to aid worthy tenants in becoming farm owners. The problem was: How shall this be done? The bill which had passed the Senate in June, r935, proposed a procedure by which the government would purchase land, develop it into suitable farms, lease it to tenants on trial for a period of not more than five years, and, if the client proved to be satisfactory, enter into a contract of sale by the terms of which the purchaser would receive title only after all, or an agreed proportion, of the purchase price had been paid. This general type of procedure was also embodied in the bill (H.R. 8) on which the Committee had been holding hearings. Practically all pèrsons who testified before the Committee favored this method of procedure. Morcover, the President's Committee had recommended this procedure, and had said: "Contracts of sale should not be undertaken until after a trial lease period not to exceed 5 years. ... At the termination of the trial period the Corporation should enter into a contract of sale under which the purchaser may pay up all the principal and obtain a deed any time aster 20 years. At the minimum rate of repayment a deed would be obtained at the end of 40 years." 19 Notwithstanding the advice of experts and the precedent set by the Senate in passing "The Farmers' Home Act" almost two years before, the Committee disapproved a program, in the latter part of

is Id, at II.

${ }^{20}$ Id. at 12. This recommendation was not concurred in by all members of the Committec. See, for instance, the dissenting statement by Edward A. O'Neal, President, American Farm Bureau Federation, id. at 22. 
March, involving the purchase of land and resale to tenants, by a vote of I3 to II. A subsequent motion to reconsider was lost by a"tie vote of 12 to 12 .

As a result of this action, another approach to the promotion of ownership had to be worked out. The Committee was willing to continue the program of rural rehabilitation loans for families who could not be aided to ownership, and the submarginal land purchase program. But it didn't want the government in "the land business." In other words, it didn't want the government to buy land and resell it to tenant farmers. A plan involving a system of long-term farm mortgage loans was the compromised result. On April 8, Congressman Jones introduced the "Farm Security Act of 1937" (H.R. 6240). It was supposed to embody the principal recommendations of the President's Committee on Farm Tenancy for federal action. Except for the loan program to promote farm ownership it was by far the most comprehensive measure to come out of the movement for tenancy legislation. The bill was divided into four titles, which provided for three separate programs of action. For the loan program to aid tenants in becoming owners, it authorized the appropriation of $\$ 50,000,000$ for each fiscal year ending prior to July $\mathrm{x}$, 1942. For short-term rural rehabilitation loans an appropriation of $\$ 75,000,000$ was authorized for this fiscal year and the next, and for the purchase of submarginal land an appropriation of $\$ 10,000,000$ for this fiscal year and $\$ 20,000,000$ for each of the three following fiscal years was authorized. This bill, however, immediately ran into difficulty from a new source. It was agreeable to the Committee on Agriculture, but the provisions for making loans to tenants with which to purchase farms commanded such little respect from House leaders and Department of Agriculture offcials that the Rules Committee of the House refused to grant a rule by which the bill could be brought to the floor for debate and discussion. This difficulty was surmounted, however, by the introduction of a new bill (H.R. 7562) which was identical with the other except that the funds authorized for appropriation were drastically reduced. ${ }^{20}$ For the loan program to aid tenants, provided for in Title I of the bill, appropriations of $\$ 10,000,000$ for the present fiscal year, $\$ 25,000,000$ for the next, and \$50,000,000 for the fiscal year ending June 30, 1940, were authorized by the new bill. No appropriations were authorized for the rehabilitation loan program provided for in Title II. The President, however, was given power to allot "such sums as he determines to be necessary to carry out the provisions of this title," from appropriations for relief or work relief. Funds for the submarginal land purchase program were reduced to $\$ 10,000,000$ for this fiscal year and $\$ 20,000,000$ for each of the two fiscal years thereafter.

It was in this form that the "Farm Security Act of 1937" was reported to the House by the Committee on Agriculture. It was brought up for discussion, under

${ }^{\infty}$ A general economy wave which swept over Congress shortly before it adjourned was partly responsible for the refusal of the Rules Committee to allow H.R. 6240 to come up for debate. Strength probably could have been mustered to overcome this feeling, however, had the measure been one which Administration leaders, both in and out of Congress, could have strongly supported. 
a special rule, on June 28 , and passed the House by a vote of 308 to 26 the following day. ${ }^{21}$

The two-day discussion of the bill in the House ${ }^{22}$ was, in large measure, a perfunctory routine affair. Under the existing rule no amendments were offered during the first day. The time was spent largely by the members of the Committee on Agriculture in describing the extent of tenancy and the general nature of the provisions of the bill under discussion. Very little attention was given to Titles II and III, providing for rural rehabilitation loans and submarginal land purchase. The tenancy situation and the provisions of Title I aimed at promoting farm ownership were the focal points of interest. The Chairman of the Committee on Agriculture, and his lieutenants, were in charge of the discussions. They pointed out that there had been much trouble in obtaining agreement on the bill in Committee. They argued, however, that tenancy was a tremendous national problem, about which something should be done, and that the enactment of this bill would provide an experimental beginning. It was frankly admitted that the small amount of funds authorized would be of negligible influence in decreasing the amount of tenancy, but the establishment of a new policy and the need for a cautious beginning were declared to be very important. There was practically no open opposition to the bill, although there were many cynical remarks about attempting to solve the tenancy problem with such a small appropriation.

As soon as the bill had passed the House it was referred to the Senate, where no action had been taken toward farm tenancy legislation since Senator Bankhead had introduced "The Farmers' Home Act" (S. I06) early in January. ${ }^{23}$ However, the Subcommittee of the Committee on Agriculture and Forestry in the Senate, which had charge of the tenancy bill, was favorable to its passage, and was merely waiting to find what disposition the House would finally make of tenancy legislation. On July I, Senator Bankhead's bill was brought to the Senate floor for discussion and debate. It had been rewritten in Committee, but the essential principles of the bill were the same as those in the measure which the Senate had passed about two years before. It was concerned wholly with aiding tenants in becoming owners. Hence, it was more limited in scope than the bill which had passed the House. It retained the proposal to set up a Corporation within the Department of Agriculture which would purchase farms and resell them to tenants on contract after a trial leasing period. In this respect it involved a different principle of procedure from that which had been incorporated in the bill that had passed the House. The funds provided for the proposed Corporation were reduced in the bill reported by the Committee to $\$ 10,000,000$ of capital stock, so that it would conform in this respect to the bill which had passed the House.

$\approx 8$ r Cong. Rec., June 29, 1937, at 8501 .

${ }^{2}$ Id., June 28 , I 937 , at $8344-8352,8359-8380,8382-8394$; June 29 , 1937 , at $8460-8502$.

2 As has been indicated, this bill was almost identical with the bill (H.R. 8) on which the Committee on Agriculture in the House had held hearings, and for which it had substituted "The Farm Security Act of 1937" (H.R. 6240 and H.R. 7562). 
Senator Bankhead's strategy on the floor was to have his bill (S. x06) passed by the Senate, then have the Senate proceed immediately to consideration of the bill passed by the House (H.R. 7562), amend the latter bill by substituting the Senate bill for it, and have the new measure sent to conference. This procedure was followed with the consequence that the attention of the Senate during its two-day discussion of tenancy legislation was directed wholly to a consideration of "The Farmers' Home Act" in the form in which it had been reported from the Committee. $^{24}$ The discussion of the bill in the Senate ${ }^{25}$ was not only perfunctory but desultory. As a matter of fact, there had been a general agreement among Senators that the bill would not be opposed. It was passed on July 2 without a record vote, and with only a few minor amendments having been made. ${ }^{28}$ The measure was immediately sent to conference, where many of its supporters hoped that it might be substituted for Title I of the House bill. It was evident that an act following the principles recommended by the President's Committee on tenancy might yet be obtained, if the Conference Committee could work out a compromise by which the House would accept the Senate measure in lieu of Title I of the bill which it had passed, and the Senate would in turn accept the Titles of the House bill which provided for rural rehabilitation loans and submarginal land retirement. However, this compromise did not eventuate. The Conference Committee ${ }^{27}$ agreed upon a measure which was only slightly different from "The Farm Security Act of I937" (H.R. 7562) which had been passed by the House. The Act was perfunctorily passed in final form by both the House and the Senate shortly after it had been reported from the Conference Committee.

\section{II}

The law as finally enacted ${ }^{28}$ has three principal purposes: $(I)$ to promote farm home ownership through a system of long-term farm mortgage loans; (2) to rehabilitate distressed farm families (who cannot be aided in purchasing a farm) through short-term loans for livestock, equipment and supplies; and (3) to provide for the development of a land conservation and utilization program, through the purchase of land submarginal for agriculture, and the development of such land into uses for which it is best suited. The Act is divided into four titles, the first three of which pertain to the procedures to be followed in attaining the three respective objectives. The last title sets up the administrative machinery for carrying out the procedures specified in the other portions of the Act. The law is to be administered

${ }^{25}$ Except for a different financing procedure, it was in substantially the same form as the bill which had passed the Senate in June, 1935 .

${ }_{x} 8 \mathrm{I}$ Cong. Rec., July I, 1937, at $861_{5}-86 \dot{2}_{2} 8,8630-8635,8638-8643 ;$ id., July 2, 1937, at $8737-8749$.

${ }^{28}$ One amendment, offered by Senator Barkley of Kentucky, changed the name of the measure to "The Bankhead-Jones Farm Tenant Act." Senator McNary of Oregon declared that, "it is the first time in the history of legislation that an act has been designated officially in the Act itself by the name of the author." ld. at 8746 .

${ }^{27}$ The Conference Committee was composed of: Senators Bankhead (D) of Alabama, Pope (D) of Idaho, Frazier (R) of North Dakota and Congressmen Jones (D) of Texas, Doxey (D) of Mississippi and Hope $(R)$ of Kansas.

${ }^{\Re}$ Bankhead-Jones Farm Tenant Act, stipra note I. 
by the Secretary of Agriculture, 29 and a corporation known as the "Farmers' Home Corporation" is created within the Department of Agriculture as an adjunct administrative agency, to which the Secretary may delegate such powers and duties as are conferred upon him by Titles I and II of the Act. ${ }^{30}$ The use of the Corporation for the promulgation of the submarginal land purchase and development program is not provided for. The Secretary is also authorized to continue to perform the functions vested in him by executive orders which transferred the Resettlement Administration to the Department of Agriculture, but, "only for the completion and administration of those resettlement projects, rural rehabilitation projects for resettlement purposes, and land development and land utilization projects, for which funds have been allotted by the President." ${ }^{31}$ In other words, the Secretary may finish the projects started by the Resettlement Administration, and administer them, but he is not authorized by the Act to start new projects of this nature, except that a continuation of the submarginal land purchase program is specifically provided for by Title III. He may sell any of the land purchased by the Resettlement Administration, or otherwise owned by the government and under his supervision, for the purpose of aiding in the promotion of farm home ownership, and may make loans to the individual purchasers for the necessary improvements on such land. ${ }^{32}$

Since the programs of rural rehabilitation loans and submarginal land purchase were originated approximately three years before the Bankhead-Jones Farm Tenant Act was passed, the only important new features of the Act are, first, it gives independent legislative authorization for these programs which had formerly been conducted under Emergency Relief Acts and, second, it provides for a tenancy program. It is toward the latter feature of the law that the balance of this discussion will be chiefly directed.

For the purpose of making farm mortgage loans to aid "farm tenants, farm laborers, sharecroppers, and other individuals who obtain, or who recently obtained, the major portion of their income from farming operations," in acquiring farms of their own, the Act authorizes an appropriation of $\$ 10,000,000$ for the present fiscal year, $\$ 25,000,000$ for the fiscal year ending June 30 , 1939 , and $\$ 50,000,000$ for each fiscal year thereafter. ${ }^{33}$ The Secretary is authorized to make such loans in the territories of Alaska and Hawaii and in Puerto Rico, as well as in the United States. ${ }^{34}$ The funds are to be distributed equitably, "among the several States and Territories on the basis of farm population and the prevalence of tenancy, as determined by the Secretary." ${ }^{35}$ Preference must be given to married persons or those with dependents and to persons who can make an initial down payment, or who own the necessary livestock and equipment for successful farming. ${ }^{36}$ "No loan shall be made for the acquisition of any farm unless it is of such size as the Secretary determines to be
${ }^{20} I d . \S_{4} \mathrm{I}$.
on Id. $\$ 43$.
${ }^{\text {so } I d . ~} \S_{40}$ (a) and (b).
st. 56.
$=1 d$. $\$ 43$.
${ }^{*}$ Id. 54.
s) Id. $\$ \$ I(\mathrm{a}), 54$.
${ }^{\text {so }}$ Id. $\S \mathrm{I}(\mathrm{b})$. 
sufficient to constitute an efficient farm-management unit and to enable a diligent farm family to carry on successful farming of a type which the Secretary deems can be successfully carried on in the locality in which the farm is situated."37

In each county in which loans are to be made the Secretary is directed to appoint, "a county committee composed of three farmers residing in the county." The members of these committees are to receive $\$ 3$ per day and travelling and subsistence expenses, "while engaged in the performance of duties under this Act but such compensation shall not be allowed with respect to more than five days in a month." The committees are to meet on the call of the County Agent, or any other person whom the Secretary may designate, in their respective counties, for the purpose of examining loan applications and appraising farms with respect to which applications for loans have been made. ${ }^{38}$ Anyone who desires to receive a loan under the provisions of this Act must file an application with the County Agent, or such other person as the Secretary may designate. ${ }^{30}$ If the county committee finds that the applicant is eligible, and that his character, ability and experience are such that he will likely be a sound risk and a successful farmer, it then must examine and appraise the farm which the applicant desires to purchase. If it finds that the farm is satisfactory, it certifies these findings together with what it deems to be the reasonable value of the farm to the Secretary. When this certification respecting the applicant and the farm has been made by the committee, and not until this has been done, the Secretary may make a loan to the applicant in an amount sufficient to purchase the farm but not in excess of the value certified by the committee. ${ }^{40}$ The funds which are loaned the applicant may be used by him for making repairs and improvements as well as for aiding in purchasing the farm. The security for the loan shall be a first mortgage or deed of trust on the farm, and repayments shall be made, "in instalments in accordance with amortization schedules prescribed by the Secretary." $\$ 1$ However, the repayment period shall not extend for more than $4^{\prime \prime}$ years. The rate of interest is to be 3 per cent per annum.

The Act provides that the Secretary may prescribe the necessary covenants in the loan and security instruments "to assure that the farm will be maintained in repair, and waste and exhaustion of the farm prevented, and that such proper farming practices as the Secretary shall prescribe will be carried out." 42 The borrower is required to pay taxes and assessments on the farm, and to carry insurance on the buildings. Should the borrower sell, assign, or otherwise transfer the farm, or any interest therein, without first obtaining the consent of the Secretary, the latter, "may declare the amount unpaid immediately due and payable." 43 The same penalty can be invoked, according to the terms of the Act, upon the borrower's failure to comply with any of the covenants and conditions contained in the loan and security instru-

${ }^{37} I d . \$ 43(\mathrm{a})$ and $(\mathrm{b})$.

${ }^{3} I d$. $\$ \mathrm{I}(\mathrm{c})$.

${ }^{\infty} I d . \xi_{2}(\mathrm{a})(\mathrm{r})$.

${ }^{\text {No } I d . ~} \$_{2}(\mathrm{a})(2),(\mathrm{b}),(\mathrm{d})$.

${ }^{2}$ Id. $\$_{3}(\mathrm{~b})(4)$.

4I Id. $\$_{3}(\mathrm{a})$.

${ }^{43} I d . \$_{3}(\mathrm{~b})(6)$. 
ments. There is also a provision in the law, made by the Conference Committee, which says that, "without the consent of the Secretary, no final payment shall be accepted, or release of the Secretary's interest be made, less than five years after the making of the loan."44 This provision was apparently inserted in an attempt to prevent speculation. As will be pointed out later its significance is very questionable as a means of preventing a borrower from turning a quick profit by selling his farm within a short time after he had purchased it.

it is evident from the tenant provisions (Title I) of this Act that in major principles it authorizes nothing more than an ordinary farm mortgage program on very liberal terms. Where necessary the purchaser may be loaned an amount equivalent to the full value of the farm which he is purchasing for a 40 -year period at $3 \%$ interest. Its benefits are limited to farm persons without land but the intention is clearly to make the loans available only to tenants who already have considerable accumulations. The highest type tenant, in other words, is the person whom the framers of this law intended it to aid. The provision for aiding them to ownership is in line with traditional American procedures, that is, by granting them farm mortgage loans.

The Act provides for departures from ordinary mortgage loan procedures mainly in the three following respects: ( $I$ ) the terms of the loans are unusually liberal, in that each borrower could obtain credit equal in amount to the full value of the security for a longer period of time and at a lower rate of interest than is ordinarily possible; (2) the instruments under which loans are made and security given must contain provisions to assure that proper farming practices, as prescribed by the Secretary, will be followed by the borrower; and (3) the borrower must obtain the consent of the Secretary before he can assign, sell or otherwise transfer the farm to another person. If the borrower does not follow the proper farming practices, or if he sells or otherwise transfers the farm, the Secretary may declare the unpaid amount of the loan immediately due and payable. The requirement that the purchaser must follow the farming practices prescribed by the Secretary is aimed partly at protecting the security for the loan, but it is of primary importance in that it opens the way for the borrower to be aided, through supervisory guidance, in planning and conducting efficient farm management practices. Even among the highest types of farm tenants, technical guidance appears very desirable as an aid to them in becoming successful farm-owners. The provision requiring that the Secretary must give his consent before the mortgaged farm is sold or transferred is obviously aimed at preventing absentee owners and persons of substantial means from taking advantage of the liberal credit terms offered by the Act through purchasing farms from the original borrowers. A fourth feature of the law which permits a practice that is not wholly new, but which, at the same time, is not commonly followed by mortgage agencies, is that the Secretary is allowed to institute a system

"Id. $53(\mathrm{~b})(6)$. 
of variable payments for collecting both the long-term loans made under Title I and the short-term rehabilitation loans made under Title II of the Act. Section $4^{8}$ of the Act says: "The Secretary may provide for the payment of any obligation or indebtedness to him under this Act under a system of variable payments under which a surplus above the required payment will be collected in periods of abovenormal production or prices and employed to reduce payments below the required payment in periods of subnormal production or prices." Obviously this provision is not mandatory, but it does afford power for experimentation with one or more variable payment schemes. For this reason its potential significance is not to be under-estimated. Highly flexible farm prices and fixed mortgage payments have, in the past, wrought immeasurable hardships on thousands of farmers. Unless prices are stabilized or mortgage payments are made flexible the future may, in this respect, bring many repetitions of the past.

\section{III}

In the preceding sections of this article an attempt has been made to give a summary of the legislative history of the Act, and to explain the principal provisions pertaining to the promotion of farm ownership. The remaining task is to point out some of its weaknesses and make suggestions for its improvement.

One feature of the Act about which there should be universal agreement is that it will provide aid for only an insignificant proportion of the total number of farm tenants, sharecroppers, and laborers, in becoming owners. There is some truth in the view expressed by Congressman Lemke, of North Dakota, when, in discussing the bill on the fioor of the House, he said: "I am surprised to hear so much fuss about nothing. If ever a mountain labored and produced a mouse, this bill is it. We have heard a lot of lip service that we are going to make farm tenants farm owners. In the light of that lip service, this bill is a joke and a camouflage." ${ }^{25}$ The I935 Farm Census indicated that there are approximately 2;865,000 farm tenants and sharecroppers in the United States. They operate farms with a total value of almost $\$ 11,000,000,000$. In addition, there are uncounted thousands of farm laborers, and still other categories of farm families, "whose insecurity," declared the President's Farm Tenancy Committee, "is a threat to the integrity of rural life." Of course, few people would seriously contend that all, or even a large percentage, of these families, should immediately be granted a federal loan with which to purchase a farm. However, if the law is sound in principle most people would agree that many more should be aided than can possibly be done with the available funds. At the same time, the fact should not be overlooked that it is the grossest of inefficiency to appropriate a few million dollars to be loaned to individual farmers scattered in 48 states, Alaska, Hawaii, and Puerto Rico. (As a practical administrative procedure, the funds will have to be allocated in such a manner that almost every Congressman with farmer constituents will have a few borrowers within his district.)

* 81 Cong. Rec., June 28 , 1937, at 835 I. 
If five per cent of the appropriation for this fiscal year is used for administrative purposes, ${ }^{46}$ the net amount to be loaned will be $\$ 9,500,000$. Assuming that the average size of the loans are $\$ 4,000$, only 2,375 farmers could be aided to ownership. ${ }^{47}$ This number is less than one-tenth of one per cent of the total number of tenants and sharecroppers in the country. If the appropriations reach $\$ 50,000,000$ per year, and $5 \%$ of this amount is used for administrative purposes, I2, I25 loans averaging $\$ 4,000$ could be made each year. This number would be less than one-half of one per cent of the tenants and sharecroppers in the United States in I935. Between I920 and 1930 there was an increase in the number of tenants and sharecroppers of more than 20,000 per year, and this rate was practically doubled from r930 to I935. It is apparent, therefore, that more than $\$ 50,000,000$ per year is necessary in order to prevent tenancy from increasing, unless there are other factors which will materially reduce the rate of growth characteristic of the past 15 years. The meager appropriations authorized for the first two years are mere "drops in the bucket." They are less than the appropriations made in many recent years for emergency feed and seed loans.

The inefficiencies of administering such small appropriations over such wide areas, and the almost negligible effects which the program will have in promoting ownership, are not, however, the only weaknesses of the law. Many students of farm tenancy problems, including most of those who were closely associated with the movement which led to the passage of this law, contend that the measure is greatly inferior to the original Bankhead-Jones tenancy bill passed by the Senate in 1935 . If this is true, then the fact that the bill authorizes the appropriation of only a few million dollars may be a point much in its favor. In other words, if the principles of the legislation are questionable, the smaller the appropriations the better, until the law can be changed or proven by experience to be acceptable. The measure provides only for a program of liberal mortgage loans and does not permit the Department of Agriculture to buy farm land, lease it to prospective purchasers for a trial period, and then convey it on contract, to the successful clients, under the terms of an agreement by which title in fee simple would not pass to the purchaser until he had made the last payment or had, at least, accumulated a sizeable equity in the holding. A purchase and resale program of this general nature would have definite advantages over the loan program provided for by the Act in, at least, the following three respects: (I) it would be less conducive to land speculation; (2) it would permit aid, without the government assuming unreasonable financial risks, to the very low income classes who are most in need; and (3) it would be better adapted to

\footnotetext{
"The Act, $\$ 6$, sets $5 \%$ as the maximum proportion of the appropriation that may be used for administration. If the borrowers are to be given considerable guidance, it is probable that administrative expenses will be the maximum.

"The figure of $\$ 4,000$ is chosen merely for illustration. It is about $15 \%$ smaller than the average value of farms operated by full owners in 1935. If the borrowers make a down payment of approximately I5 per cent and purchase farms of about the same value as those operated by full owners the loans should average in the neighborhood of $\$ 4,000$.
} 
areas where the present holdings are large, such as the plantation areas of the South, and to situations where it is desirable to bring large bodies of new land into cultivation.

The general problem of land speculation is tremendously important to the welfare of agriculture, and a potent cause of farm tenancy. Yet there is reason to believe that this law will have a direct effect in encouraging speculative activities to a much greater extent than a law providing for a purchase and resale program. This appears to be true for two major reasons. First, many more buyers of land will be added to the market. Second, there are inadequate safeguards against alienation of the holdings purchased by the liberal loans. The expenditure of several million dollars per year for the purchase of farms would have a tendency to raise land values, whether the expenditures were made directly by a government agency or by individual farmers. Nevertheless, when the government is the only new buyer added to the market this tendency is likely to be much less than when many farmerbuyers are added. With respect to the land in any given community the government could exercise considerable independence. If landowners were demanding unreasonable prices, it could cease its buying activities in that community and proceed to purchase in another area. Under the loan program, on the other hand, such independence is hardly possible. In order to aid twenty tenants in a given county there will be twenty new bidders for farms in that county. Two or more of them may be bidding for the same farm. If the government can be persuaded, through the local county committee, into loaning practically all of the money for the purchase of these farms, both the buyers and the sellers may enjoy the sport of bidding up prices. Moreover, the loan program will tend to draw into the ranks of the borrowers every Tom, Dick and Harry who thinks that land values are going to rise and that he stands a chance of making a profit by gambling with the government's money. The law specifically provides that, at the end of five years, any borrower is free to pay up the loan and sell the farm to whomsoever he desires. ${ }^{48}$ Obviously, if a man can borrow all of the money with which to purchase a farm, and with land values rising as they have been for the last two or three years, he stands an excellent chance of making a profit by selling it five years later at a higher price. Yet he has practically no chance of incurring a loss, because he can let his payments go delinquent at any time, and, under the present laws of many states, regaining possession of a farm through foreclosure often requires one to three years. Of course, the borrower must obtain the Secretary's consent to sell the farm or have the cash with which to pay off the loan. Sales for cash may not be difficult to make, however, if

«s Unless there are special penalty provisions placed in the loan agreement, a borrower who can scll his farm for cash, or otherwise obtain the funds with which to pay off the loan, will not be prevented from selling at any time. Without suclr penalty provisions a borrower can sell the farm a month, or cven a week, after he receives title. The only recourse the law gives the Secretary is to declare the loan to be immediately due and payable. If the borrower has the funds, which presumably he has if he sold for cash, he can immediately repay the loan. On the transaction he may have made a neat profit within a very short period. It is not certain, moreover, that penalty provisions necessary to prevent such occurrences can be practicably invoked. 
land values rise considerably, because a buyer could usually obtain a loan on the farm from some other mortgage agency.

Restrictions on alienation which will satisfactorily prevent the type of land speculation which has just been described are virtually precluded by a program for promoting ownership by mortgage loans. Speculation of this kind can be prevented, however, by the government's purchasing the land and reselling it under an agreement by which title would not be delivered until the purchaser had a substantial equity in the holding. It was for this reason that the President's Committee recommended that title should not be given until the farm had been completely paid for, and that final payment not be accepted until, at least, 20 years had elapsed from date of purchase. A restriction of this nature should not be interpreted to be a means by which the farmer is bound to the soil. The purchaser could be allowed to sell his equity at any time provided that the administrative agency had an option to purchase it, and, in order to make the plan most workable, also the right to approve the buyer. In order to prevent the type of speculation which can so easily arise under the loan program the option on the purchaser's equity should be at a price equivalent to the amount which he has paid on the principal. Under such a scheme the value of a given holding which a tenant is purchasing might be double the purchase, price at the time he wants to sell his equity, and yet if the administrative agency exercised its option to purchase his equity, instead of approving some individual who might want to buy it, he would receive only the amount which he had paid on the loan. If, on the other hand, the value of his holding had declined to one-half the purchase price, he would still receive the total amount of the payments which he had made. An administrative agency which exercised its options of this nature in order to prevent its clients from taking a profit from a rise in land values would be morally obligated to prevent them from taking a loss when land values declined. Yet in doing this it would be throwing itself open to severe financial drains during long depression periods when land values are greatly lowered. It was in view of this difficulty that the President's Committee recommended that the Administrative Agency's option on the purchaser's equity should be at a price equivalent to the "current appraised value, sharing with him pro rata, according to the amount of debt remaining unpaid, any increase or decrease in value not attributable to wastage or improvements for which the holder is responsible." ${ }^{49}$ From some viewpoints this is a more equitable plan than, one under which the equity would be purchased at a price equivalent to the amount which the tenant-purchaser has paid on the principal of the debt. Under either plan, however, unreasonable speculative profits can be prevented without binding the man to the soil.

The second major advantage of a purchase and resale program is that it is more conducive to the promotion of ownership among persons of a low economic status, especially if they have had little experience in managing their own affairs, than is

${ }^{\circ}$ Farm Tenancy, Report of the President's Commitiee (Feb. 1937) 12. 
the loan program provided for by the new law. If the government buys the land, and leases it to prospective purchasers for a trial period of three to five years before giving them a contract for title, it has a much better method of selecting the families to be aided to ownership than through a county committee. A farmer's ability and integrity can be tested, the family's adjustment to a particular farm can be known, and the inexperienced can be taught to assume the responsibilities of ownership and management. As a consequence, the beneficiaries of the program could be drawn from the lower classes of tenants, sharecroppers, and laborers who are least able to help themselves. It is very questionable, for instance, whether the present law permits the inauguration of a program which will aid the ordinary southern sharecropper and laborer. Only the highest type of tenant can be selected for a loan, unless the Department of Agriculture is willing to assume unusual risks with the funds and the criticisms and expense of carrying through many foreclosure suits. In most jurisdictions it is much easier to regain possession of a farm conveyed on contract, than it is to foreclose a mortgage. Hence, the purchase and resale scheme, such as that recommended by the President's Committee and embodied in most of the tenancy bills considered by Congress preceding the passage of the existing Act, would give the administrative agency more power to supervise the purchaser's farming operations, even after the end of the trial leasing period, than can practically be exercised under the present law. The necessity for supervision is great in the South, and fairly important in many other areas, if any significant proportion of "the underdogs" in agriculture are to be given a secure relationship to the land. It can be provided in the simplest and most straightforward manner by the government's buying suitable land and conveying it in fee simple only after the purchaser has. leased it for a period and accumulated a considerable equity in it while holding under a contract for title.

That a purchase and resale program is better fitted than a loan program to areas where land is held in large tracts, or where new land is to be brought into cultivation, is quite obvious. It will be difficult, for instance, for a tenant to purchase 40 or 80 acres from a southern plantation owner unless he is willing to take it near the edge of the plantation. This, of course, is not a serious problem, but there are many instances in which the government might better purchase an entire plantation and sub-divide it into family-sized farms for resale to tenants, than to loan money with which the individual tenants would buy separate tracts from the one large owner. In many areas where new land might be brought into cultivation it is often necessary, or, at least, most economical, to construct drainage or levee systems far too large to be undertaken by an individual farmer, and yet too small to warrant the organization of a special assessment district. In such instances the loan program is of little yalue, whereas a purchase and resale program would enable the government to bring such land into cultivation. In many areas it would be wise to do this instead of assisting farmers to purchase badly depleted soil now in cultivation. 
There are several other ways in which a purchase and resale program would be superior to the individualistic loan program provided for by the present law. Few of these are of importance, however, with the possible exception that a much better spatial distribution of the farms could be obtained under the former type of program. The efficacy of closely settled or village-type farm communities is, of course, a highly debatable question, which need not be entered into here. Most persons will agree, however, that more efficient administration could be had if a score or more of the beneficiaries of such a program were situated within one or two rural communities than if they were scattered over a whole county. Moreover, they might more easily group themselves into co-operatives for buying and selling commodities or for owning large and expensive units of farm machinery. The operations under the present law may, of course, result in many situations where the spatial distribution of the borrowers is very satisfactory. However, the same end could be more consistently attained with a program of land purchase and resale.

In view of the shortcomings of the law which have been discussed it appears that it could be greatly improved by supplanting it with a measure such as the bill (S. 2367) passed by the Senate in June, I935, and which has been described in earlier pages of this article. The enactment of that bill into law would have permitted the inauguration of a loan program such as that authorized by the existing Act, and, at the same time, would have allowed the development of a land purchase and resale program, such as that recommended by the President's Committee on Farm Tenancy. The same end might now be attained by supplementing the present Act with a new law authorizing the Secretary of Agriculture to carry out an ownership program under a purchase and resale scheme. Except for its inducements to speculation, the loan program is a fairly acceptable means of aiding the tenants with experience, ability and high economic status. But if the southern sharecropper, the migratory laborer of the West, and the maturing farm youth of the Dust Bowl and the Appalachian highlands, are to be given a secure relationship to the land, either through ownership or by other means, the government will have to take that much criticized step of "going into the land business." If land speculation is to be curbed, if states are to be aided and encouraged to enact laws to improve farm leases, and if thousands of heavily indebted owners are to be prevented from losing their farms, much legislation is yet needed. In short, if America is to have increased farm security and a greater stability of rural life, Congress has yet to act. 